African Crop Science Journal by African Crop Science Society is licensed under a Creative Commons Attribution 3.0 Uganda License. Based on a work at www.ajol.info/ and www.bioline.org.br/cs DOI: https://dx.doi.org/10.4314/acsj.v26i4.1

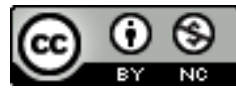

\title{
EVALUATION OF BIO-PHYSIOLOGICAL AND YIELD RESPONSES OF STAY GREEN QTL INTROGRESSION SORGHUM LINES TO POST-FLOWERING DROUGHT STRESS
}

\author{
K. AYALEW, A. ADUGNA ${ }^{1}$, M. FETENE and S. SINTAYEHU
}

\author{
Addis Ababa University, Department of Plant Biology and Biodiversity Management, P. O. Box 1176, \\ Addis Ababa, Ethiopia \\ ${ }^{1}$ Advanta Seeds Ltd., P. O. Box 10438, Eldoret, Kenya \\ Corresponding author: asfaw123@ rediffmail.com
}

(Received 2 January, 2018; accepted 2 November, 2018)

\begin{abstract}
Drought is the most drastic abiotic stress that limits crop production in sub-Sahara Africa. Sorghum (Sorghum bicolor (L.) Moench) is among the most climate resilient cereals of the future due to its tolerance to drought and heat. Thus, identification of tolerant genotypes and plant characteristics that contribute to drought adaptation is timely. The objective of this study was to evaluate the response of 12 genotypes, including seven Stay-green (Stg) QTL introgression sorghum lines and their two donor; and three recurrent parents, to induced postflowering drought stress. The recurrent parents were varieties released for drought prone lowlands of the country, and the donor parents were lines known to have stay-green properties. The study was conducted at Werer, in the Great Rift-valley of Ethiopia, during the off-season of 2014 under well-watered and water limited conditions. Significant differences $(\mathrm{P}<0.05)$ were observed among genotypes under water deficit regimes, for all measured physiological, biochemical (proline content), yield and yield related traits. Three Stg QTL introgression lines showed better tolerance to drought than their recurrent parents, as reflected by yield and maintenance of green leaf area. Three Stg QTL introgression lines, Teshale/E36-1, Gambella/B35-5 and Meko/B35-12, gave the highest grain yield under post-flowering drought stress, and B35 and Teshale/B35 gave the poorest yield under similar conditions. Therefore, these improved lines bear potential for use as alternatives in breeding programmes and for possible release in parts of the country where post-flowering drought stress is frequent. Proline content, weight of hundred seeds (HSW) and $\mathrm{CO}_{2}$ assimilation are effective screening tools for Stg property due to their high correlation with other parameters.
\end{abstract}

Key Words: Post-flowering, proline, Sorghum bicolor

\section{RÉSUMÉ}

La sècheresse est le stress abiotique le plus drastique qui limite la production agricole en Afrique Sub-saharienne. Le sorgho (Sorghum bicolor (L.) Moench) est parmi les céréales les plus résilientes au climat pour le futur dû à sa tolérance à la sécheresse et à la chaleur. Donc, l'identification des génotypes tolérants et les caractéristiques des plants qui contribuent à l'adaptation à la sécheresse est opportune. L'objectif de cette étude était d'évaluer la réponse de 12 génotypes, comportant sept lignées de sorgho conférant l'introgression des QTL des attributs verts (Stg), leurs deux donneurs ; et les trois parents récurrents, au stress de la sécheresse post floraison induite. Les parents récurrents ont été les variétés libérées sensibles à la sécheresse dans les plaines du pays, et les donneurs ont été les lignées connues pour leurs propriétés relatives aux attributs verts. L'étude a été conduite à 
Werer, dans la grande vallée du Rift d'Ethiopie, pendant la contre saison de 2014 dans des conditions d'irrigation abondante et d'irrigation limitée. De différences significatives $(\mathrm{P}<0.05)$ ont été observées entre les génotypes sous des régimes de déficit hydriques, pour tous les traits physiologiques, biochimiques (teneur en proline), le rendement et les composantes de rendement. Trois lignées d'introgression de Stg QTL ont montré de meilleure tolérance à la sécheresse que leurs parents récurrents, comme reflété par le rendement et la maintenance de la surface verte de la feuille. Trois lignées d'introgression de Stg QTL, Teshale/E36-1, Gambella/B35-5 et Meko/ B35-12, ont donné le plus haut rendement sous le stress de sécheresse de post floraison, et B35 et Teshale/B35 ont donné le plus faible rendement dans des conditions similaires. En conséquence, ces lignées améliorées détiennent tout le potentiel pour leur usage comme alternatives dans des programmes d'amélioration génétiques et pour une libération possible dans les régions du pays où le stress de la sécheresse post floraison est fréquent. La teneur en proline, le poids de 100 graines (HSW) et l'assimilation du $\mathrm{CO}_{2}$ sont des outils effectifs de criblage pour la propriété de Stg due à leur forte corrélation avec les autres paramètres.

Mots Clés: Post-floraison, proline, Sorghum bicolor

\section{INTRODUCTION}

Drought is one of the primary causes of household food insecurity in sub-Sahara Africa, as the food production trend correlates with the rainfall pattern (Bekele, 2001). Drought stress occurs anytime during the life cycle of the crop (Adugna and Tirfesa, 2014). However, major crop yield decline due to moisture deficit during flowering and grain filling stages (Ali et al., 2011); by reducing the number and weight of seeds (ICRISAT, 2013).

Sorghum (Sorghum bicolor (L.) Moench) can adapt better to adverse growing conditions such as drought, than other cereals such as maize (Zea mays L.) (Dahlberg et al., 2011). It can produce grain in areas too dry for maize; such as areas having less than $250 \mathrm{~mm}$ average annual rainfall (Chamberlin and Schmidt, 2011). Sorghum genotypes differ in their ability to avoid leaf senescence and maintain green leaf area until maturity (Adugna and Tirfessa, 2014). Leaf senescence is symptomised by visual leaf symptoms such as loss of chlorophyll pigments (yellowing), wilting and eventual abscission (He et al., 2005).

Stay green $(\mathrm{Stg})$ is a property of plants to maintain prolonged green leaf area and stalk under post-flowering drought stress (Rosenow et al., 1983). Sorghum genotypes that possess Stg trait are also reported to have reduced lodging and resistance to stalk rots (Borrell et $a l ., 2000)$. It is used as a strategy to reduce the effect of drought at grain filling, as drought stress during this stage in sorghum usually results in rapid premature plant senescence, which may in turn reduce grain yield. Therefore, Stg is considered an important genetic trait associated with drought tolerance and has been mapped to a number of key chromosomal regions (QTLs) in sorghum (Borrell et al., 2014).

The International Crops Research Institute for the Semi-arid Tropics (ICRISAT) and the Ethiopian National Sorghum Improvement Programme at Melkassa Agricultural Research Center (MARC) carried out collaborative marker assisted backcrossing (MAB) (Adugna and Tirfessa, 2014), to improve the terminal drought tolerance of the locally adapted high yielding varieties. As a result, a fairly large number of Stg QTL introgression sorghum lines were developed. Three separate experiments were organised to test the various QTL introgression lines under post-flowering drought stress. Adugna and Tirfessa (2014) evaluated one set of the lines for morphological, yield and yield related characters. In addition to these characters, Sintayehu et al. (2018) evaluated another set of introgression lines (selections) for physiological and root characters in addition to yield and yield related traits. Both studies found that many of the introgression lines were better than their susceptible recurrent parents for key traits. However, we believed that 
inclusion of proline content in the study might reveal better insights about the response of Stg introgressed lines under drought stress. This study was done concurrently with the latter study and designed to include proline The objective of the present study was to determine the extent of drought stress tolerance of the Stg introgressed lines through biophysiological and yield related traits.

\section{MATERIALS AND METHODS}

Study area. Stay-green QTL introgression was done at Melkassa Agricultural Research Center from 2006 to 2008. The field experiment was conducted during the offseason of February to June 2014 at the experimental field of Werer Agricultural Research Center $\left(40^{\circ} 11^{\prime} \mathrm{E}, 09^{\circ} 22^{\prime} \mathrm{N}\right.$, altitude $750 \mathrm{~m}$ asl), located in the Afar Regional State, $280 \mathrm{Km}$ east of the capital, Addis Ababa in Ethiopia. The site soil was black alluvial, with a pH and electrical conductivity of 6.9 and 0.78 $\mathrm{dS} / \mathrm{m}$, respectively. Its annual rainfall ranged from 200 to $500 \mathrm{~mm}$, with mean minimum temperatures of $15.2{ }^{\circ} \mathrm{C}$ in December, $23{ }^{\circ} \mathrm{C}$ in June and the mean maximum temperatures are $32.5^{\circ} \mathrm{C}$ in December and $38{ }^{\circ} \mathrm{C}$ in June. Weather data during the experimental periods were collected from Ethiopian Meteorological Agency (EMA) and showed that there was small rainfall during the period of the experiment (EMA, 2014).

Plant material. Seven Stg QTL introgression sorghum lines, which were derived through marker assisted backcrossing (Gambella 1107/ B35-1, Gambella 1107/B35-5, Gambella 1107/ E36-1, Teshale/E36-1, Teshale/B35, Meko/ B35-8 and Meko/B35-12); two known Stg QTL donor parents (B35 and E36-1); and three senescent recurrent parents (Gambella 1107, Teshale and Meko), constituted the experimental materials. Seeds of all of the 12 varieties and lines (hereafter referred to as genotypes) were obtained from the Ethiopian Sorghum Research Programme at Melkassa
Agricultural Research Center. The recurrent parents were high yielding varieties, released for drought prone environments, but their yield performance had been repeatedly affected by post-flowering drought stress (Adugna and Tirfessa, 2014). Moreover, they were known to have good grain quality for the preparation of local food stuffs (Adugna, 2007).

The variety Gambella 1107 was an Ethiopian landrace selection, originally collected from Gambella region; while Meko (M36121) and Teshale (3443-2-OP) were exotic sorghum varieties introduced from ICRISAT and released in Ethiopia in 1997 and 2002, respectively (Adugna, 2007). The Stg donor parent, B35, was a durra sorghum, a derivative of a landrace germplasm accession from Ethiopia (Reddy et al., 2009). It was the best characterised source of Stg for postflowering drought tolerance in sorghum. E361 was also a known source of Stg trait being used in breeding programmes and was of Ethiopian origin (Reddy et al., 2009).

Experimental procedures. Treatments included 12 sorghum genotypes (seven QTL introgression lines, two Stg donor lines and three senescent recurrent parents) and two irrigation regimes (well-watered and water limited). The experiment was laid out in splitplot design with three replications. The two irrigation regimes were assigned as main plot factors, whereas the 12 sorghum genotypes were the sub-plot treatment factors. The plots in the water limited treatment were irrigated until flowering and, thereafter, irrigation was withheld. Those in well-watered treatment continued irrigation until physiological maturity. Irrigation was done using fresh water pumped directly from River Awash every seven days by flooding in the furrows, until the furrows were full. Each subplot consisted of three rows of $3.5 \mathrm{~m}$ length and $0.80 \mathrm{~m}$ interrow spacing. The genotypes were randomised in each main plot.

Seeds of the experimental genotypes were sown by hand drilling in rows. They received 
the first irrigation on February 3, 2014. Two weeks after emergence, the plants were thinned to one plant per hill to maintain the recommended spacing of $15 \mathrm{~cm}$.

Fertilisers were applied as per the local recommendations (Reddy and Georgis, 1993). Accordingly, $36.23 \mathrm{~g} \mathrm{P}_{2} \mathrm{O}_{5}$ and $14.18 \mathrm{~g} \mathrm{~N}$, which is equivalent to $100 \mathrm{~kg}$ per hectare of DAP $\left(46 \% \mathrm{P}_{2} \mathrm{O}_{5}, 18 \% \mathrm{~N}\right)$ was applied per plot in seed furrows during sowing; and $36.23 \mathrm{~g}$ of $\mathrm{N}$ per plot, which is equivalebt to $100 \mathrm{~kg}$ per hectare of urea was applied as top dressing when the plants reached at knee height stage.

The experimental field was kept free from weeds throughout the study period by hand weeding. Moreover, Karate 5\% EC, was sprayed at the rate of $320 \mathrm{~mm}$ per hectare as needed to control stem borers and shoot flies.

Data collection and analysis. Data were recorded on five plants, which were randomly tagged in each plot in three ways. Leaf relative water content (RWC) and chlorophyll content were recorded twice, on the $30^{\text {th }}$ day after the date of $50 \%$ flowering and on the $15^{\text {th }}$ day after the date of first measurement on the tagged plants. Leaf Stg rating was recorded at physiological maturity. Yield and yield related parameters were recorded after harvesting.

Leaf senescence rating at physiological maturity, which is reportedly an excellent indicator of Stg (Sanchez et al., 2002), was recorded at this stage. The rating was done using 1 to 5 scales by visually observing the leaf area and determining whether it was senesced, following the procedure of Rosenow (1993). Completely green leaves without any leaf area death were rated 1 and leaves with leaf area death from $1-25 \%$, rated $2,26-50 \%$, rated $3,51-75 \%$, rated 4,76 to $100 \%$ were rated 5 (Rosenow, 1993).

Gas exchange measurements $\left(\mathrm{CO}_{2}\right.$ assimilation rate and transpiration rate) were measured simultaneously using Lc pro+ portable photosynthesis system (ADC Bioscientific Ltd, Hoddesdon, England). Lc pro+ portable photosynthesis system measures gas exchange in open system in which fresh air is passed through the plant leaf chamber on a continuous manner. When $\mathrm{CO}_{2}$ is taken up by leaves in the process of photosynthesis, it induces more atmospheric $\mathrm{CO}_{2}$ to diffuse through stomata, while water vapour can easily diffuse out by the process of transpiration.

Measurements were taken early in the morning on a fully expanded, deep green, and healthy leaves, which were fully exposed to sun light to capture their full function. The average of the five sampled plants was recorded as plot value. Water use efficiency (WUE) was calculated by taking the ratio of $\mathrm{CO}_{2}$ assimilation rate to water lost due to transpiration (Barrs, 1968).

Chlorophyll content index reading was also taken using a hand held Chlorophyll Content Meter/ CCM-200 plus (Apogee Instruments, Inc. Logan, USA). The ratio of absorption of the light emitted from the instrument at two wave lengths $\left(931 \mathrm{~nm} 653 \mathrm{~nm}^{-1}\right)$ is the basis for the measurement of chlorophyll content index (www.apogeeinstruments.com). As the light absorption characteristics of the leaf at the two wavelengths are affected by leaf chlorophyll content, the measured values provide an indication of the relative amount of total chlorophyll present in the leaves.

Leaf relative water content was determined from fresh, green and fully expanded leaves from five sample plants, following the procedure of Barrs and Weatherly (1962). Leaves were collected in polyethylene bags and preserved in an ice box. In the laboratory, $2.5 \mathrm{~cm} \times 2.5 \mathrm{~cm}$ leaf discs were taken by excluding midribs. Fresh weight (FW) was determined and then, the leaf disc was transferred into a Petri dish containing distilled water, and kept for 24 hours. After 24 hours, the leaf discs were taken out of the distilled water and dried on tissue paper to remove the surface water droplets and immediately weighed to obtain turgid weight (TW). Thereafter, they were oven dried to a constant temperature of $80{ }^{\circ} \mathrm{C}$ for 24 hours, and 
weighed to get dry weight (DW). The RWC was calculated as:

$$
\operatorname{RWC}(\%)=\frac{\text { FW }- \text { DW }}{\text { TW }- \text { DW }} \times 100
$$

Equation 1

Where:

FW $=$ Fresh weight, DW $=$ Dry weight, and $\mathrm{TW}=$ Turgid weight

Proline content of the leaves was measured spectrophotometrically from fully expanded leaves, following the Ninhydrin methods of Bates et al. (1973), at the Eco-physiology laboratory of Addis Ababa University. The reagent Acid-ninhydrin was prepared by dissolving $1.25 \mathrm{~g}$ of ninhydrin in $30 \mathrm{ml}$ of glacial acetic acid and $20 \mathrm{ml}$ of $6 \mathrm{M}$ phosphoric acid.

The weighed fresh leaf sample $(0.5 \mathrm{~g})$ was ground using a mortar and pestle and homogenised with $10 \mathrm{ml}$ of $3 \%$ sulfosalicylic acid. The homogenate was filtered through Whiteman No. 1 filter paper (Whiteman, Missouri, USA) and the filtrate was used for proline estimation. Two milliliters of filtrate from each sample was taken in separate test tubes; and in each test tube $2 \mathrm{ml}$ of acid ninhydrin reagent and $2 \mathrm{ml}$ of glacial acetic acid were added and boiled in a hot water bath for one hour. Then, the test tubes were transferred to ice water-bath for one hour to cool, and $4 \mathrm{ml}$ of toluene was added. The mixture was shaken thoroughly and allowed to settle at room temperature for 30 minutes until it formed two separate layers. The upper toluene layer containing the colour complex due to proline ninhydrin reaction was transferred to a separate test tube and absorbance was read in spectrophotometer (Dalian Cebon Instruments Co., Ltd, Liaoning, China) at $520 \mathrm{~nm}$. The proline concentration was determined from the standard curve and expressed in moles of proline per gram fresh weight of the leaf as:

Mole proline $g=$

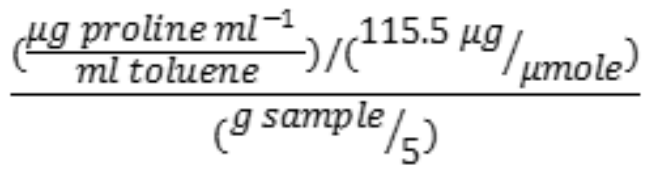

Equation 2

At maturity, all the panicles from the tagged plants in each plot were harvested, sun dried, threshed, cleaned and weighed. Panicle weight and grain yield were recorded per plot, and later converted to per hectare. The weight of hundred seeds (HSW) was determined from dry seeds at $12.5 \%$ moisture level. To obtain shoot dry matter weight (SDW) at maturity, the shoots of the tagged sample plants were harvested and separated into stems and leaves. These parts were dried at $80^{\circ} \mathrm{C}$ for 24 hours in an oven and dry weights of separated plant parts recorded and summed up.

All the collected quantitative data were subjected to analysis of variance (ANOVA) using STATISTICA Software Version 7 (STATISTICA Inc., USA). Significant means of each measured data were separated using Tukey's multiple range test at the probability of $5 \%$. Correlation coefficients were computed among the studied parameters using SAS version 9.0 Software.

\section{RESULTS}

Morphological characters. There were significant difference $(\mathrm{P}<0.05)$ among the genotypes for leaf senescence rating under the two water regimes (Table 1). As expected, B35 and E36-1 had the lowest leaf senescence rating (least sensitive) of all the parental lines. On the contrary, Gambella 1107 showed the highest rating (the most sensitive) under stressed condition. Meko/B35-12, Gambella/ B35-5 and Teshale/E36-1 showed the lowest 
TABLE 1. Effect of post flowering drought stress on leaf senescence rating (LSR), leaf chlorophyll content $\left(\mathrm{LCC}, \mu \mathrm{g} \mathrm{cm}^{-2}\right.$ ), and relative water content (RWC, \%) of sorghum genotypes in Ethiopia

\begin{tabular}{|c|c|c|c|c|c|c|}
\hline \multirow[t]{2}{*}{ Genotypes } & \multicolumn{2}{|c|}{$\mathrm{LSR}^{*}$} & \multicolumn{2}{|c|}{$\mathrm{LCC}$} & \multicolumn{2}{|c|}{ RWC } \\
\hline & WW & DS & WW & DS & WW & DS \\
\hline Teshale/B35 & $2.89^{\mathrm{dfg}}$ & $3.31^{\mathrm{abcd}}$ & $52.94^{\mathrm{ab}}$ & $44.08^{\mathrm{abcde}}$ & $78.37^{\mathrm{abc}}$ & $53.07^{\mathrm{g}}$ \\
\hline Teshale/E36-1 & $2.72^{\mathrm{f}}$ & $3.11^{\mathrm{b}}$ & $42.66^{\text {abcde }}$ & $41.99^{\text {abcde }}$ & $85.75^{\mathrm{a}}$ & $67.59^{c}$ \\
\hline Gambella 1107/E36-1 & $2.88^{\mathrm{dfg}}$ & $3.28^{\mathrm{abcd}}$ & $37.38^{\mathrm{b}}$ & $31.86^{\mathrm{d}}$ & $79.59^{\mathrm{abc}}$ & $56.97^{\mathrm{f}}$ \\
\hline Gambella 1107/B35-code1 & $2.96^{\mathrm{dfg}}$ & $3.38^{\mathrm{abc}}$ & $30.71^{\mathrm{de}}$ & $27.54^{\mathrm{e}}$ & $76.83^{\mathrm{abcd}}$ & $53.39^{\mathrm{g}}$ \\
\hline Gambella 1107/B35-code5 & $2.83^{\mathrm{dfg}}$ & $3.08^{c}$ & $41.43^{\text {abcde }}$ & $40.99^{\text {abcde }}$ & $85.71^{\mathrm{a}}$ & $61.92^{\mathrm{e}}$ \\
\hline Meko/B35-code8 & $2.90^{\mathrm{dfg}}$ & $3.31^{\mathrm{abcd}}$ & $46.76^{\mathrm{abcd}}$ & $41.00^{\mathrm{abcde}}$ & $74.19^{\mathrm{abcde}}$ & $56.44^{\mathrm{fg}}$ \\
\hline Meko/B35-code12 & $2.85^{\mathrm{dfg}}$ & $3.06^{\mathrm{d}}$ & $38.47^{\text {abcde }}$ & $36.28^{\text {bce }}$ & $84.65^{\mathrm{ab}}$ & $64.26^{\mathrm{d}}$ \\
\hline Teshale & $2.78^{\mathrm{e}}$ & $3.58^{\mathrm{ab}}$ & $50.25^{\mathrm{abc}}$ & $36.76^{\text {bcde }}$ & $85.7^{\mathrm{a}}$ & $52.94^{\mathrm{g}}$ \\
\hline Gambella 1107 & $2.86^{\mathrm{dfg}}$ & $3.64^{\mathrm{a}}$ & $51.64^{\mathrm{abc}}$ & $38.92^{\text {abcde }}$ & $80.74^{\mathrm{abc}}$ & $53.03^{\mathrm{g}}$ \\
\hline Meko & $2.88^{\mathrm{dfg}}$ & $3.58^{\mathrm{ab}}$ & $44.28^{\mathrm{abcde}}$ & $33.73^{\mathrm{c}}$ & $82.66^{\mathrm{ab}}$ & $53.07^{\mathrm{g}}$ \\
\hline E36-1 & $2.50^{\mathrm{g}}$ & $2.57^{\mathrm{g}}$ & $49.75^{\mathrm{abc}}$ & $43.53^{\text {abcde }}$ & $83.96^{\mathrm{ab}}$ & $74.66^{\mathrm{abcde}}$ \\
\hline B35 & $1.34^{\mathrm{h}}$ & $1.36^{\mathrm{h}}$ & $56.11^{\mathrm{a}}$ & $47.66^{\mathrm{abcd}}$ & $83.05^{\mathrm{ab}}$ & $71.37^{\mathrm{b}}$ \\
\hline
\end{tabular}

$* \mathrm{WW}=$ well-watered, DS $=$ drought stressed

rate of senescence of all the introgression lines, whereas, Gambella 1107/B35-1, Teshale /B35 and Meko/B35-8 showed the highest leaf senescence rating. Under the stressed condition, all of the introgression lines showed lower leaf senescence rating than their recurrent parents (Table 1).

\section{Physiological and biochemical characters}

Relative water content. There were significant differences $(\mathrm{P}<0.05)$ among the genotypes for leaf RWC under the two water regimes (Table 1). All the genotypes showed a reduction in RWC due to drought stress. Under drought stressed condition, E36-1, B35 and Teshale/E36-1 showed the highest RWC in that order. The recurrent parents, Meko, Gambella 1107 and Teshale possessed the lowest leaf RWC of all the genotypes under drought stressed condition. However, all of the introgression lines had higher RWC than their recurrent parents.

Chlorophyll. There were significant differences $(\mathrm{P}<0.05)$ in chlorophyll content among the genotypes (Table 1). Leaf chlorophyll content (SPAD values) of the genotypes differed between the two water regimes, and post-flowering drought significantly reduced the leaf chlorophyll content of all the genotypes. Under drought stressed condition, B35, Teshale/B35, E36-1, Teshale/E36-1 and Meko/B35-8 maintained the highest chlorophyll content; while Teshale, Meko/ B35-12, Meko, Gambella 1107/E36-1 and Gambella 1107/B35-1 had the lowest values of this parameter (Table 1). Chlorophyll content of the leaves among genotypes ranged from $30.71 \pm 1.66 \mathrm{mg} \mathrm{cm}^{-2}$ for Gambella 1107/ B-35-1 to $47.66 \mathrm{mg} \mathrm{cm}^{-2}$ for B35 under drought stressed condition. Under the stressed condition, all introgression lines, except crosses of Gambella 1107 (Gambella 1107/ B35-1 and Gambella 1107/E36-1), had higher chlorophyll content than their recurrent parents (Table 1).

Transpiration. Transpiration rate also showed significant difference $(\mathrm{P}<0.05)$ among the genotypes under the two water regimes (Table 1). Rate of transpiration was significantly lower under water stressed treatments than with irrigation, and showed a general decreasing pattern with drought stress. Under the irrigated condition, Teshale/B35 had 
the highest transpiration rate; followed by Teshale/E36-1 and Gambella 1107/E36-1. The lowest transpiration rate was recorded by B35 under both water regimes. On the other hand, the maximum transpiration rate under water limited condition was observed in Teshale/B35 (Table 2). Under the water stressed condition, all of the introgression lines had higher transpiration rate than their recurrent parents.

Water use efficiency. Significant differences $(\mathrm{P}<0.05)$ were observed among the genotypes for WUE under the two contrasting water regimes (Table 2). E36-1, Gambella 1107/B355 and B35 had the highest WUE of all the genotypes under drought stressed condition. The two most water use efficient stg introgression lines were Teshale/E36-1 and Gambella 1107/B35-5. All of the introgression lines, except Gambella 1107/B35-5 and Meko/ B35-8 had higher WUE than their recurrent parents under drought stressed condition (Table 2).

$\mathrm{CO}_{2}$ assimilation. There were significant variations $(\mathrm{P}<0.05)$ among the genotypes for
$\mathrm{CO}_{2}$ assimilation rate under the two water regimes (data not shown). A decrease in $\mathrm{CO}_{2}$ uptake was observed in all the genotypes under drought stressed condition. Under this condition, Gambella 1107/B35-5 and Teshale/ E36-1 had slightly superior assimilation rates than the rest of the genotypes. Under wellwatered condition, all of the introgression lines had lower assimilation rate than their respective recurrent parents; but under drought stressed condition, all of the introgression lines except Meko/B35-8 and Gambella 1107/B35-1, had higher assimilation rate than their recurrent parents (Table 2).

Proline content. Proline content showed significant difference $(\mathrm{P}<0.05)$ among the genotypes under both water regimes (Table 2). All genotypes increased in level of proline under drought stress. The level of increase ranged between $79.4 \%$ (B35) and 86.3\% (E361). Under water stressed condition, Teshale/ E-36-1 had the highest proline content followed by E36-1 and Gambella/B35-5 (Table 2). Maximum proline content was observed in better yielding lines, Teshale/E36-1,

TABLE 2. Effect of post-flowering drought stress on $\mathrm{CO}_{2}$ assimilation rate, transpiration rate, water use efficiency and proline content of sorghum genotypes in Ethiopia

\begin{tabular}{|c|c|c|c|c|c|c|c|c|}
\hline \multirow[t]{2}{*}{ Genotypes } & \multicolumn{2}{|c|}{$\mathrm{AR}^{*}$} & \multicolumn{2}{|c|}{ TR } & \multicolumn{2}{|c|}{ WUE } & \multicolumn{2}{|c|}{ Prol } \\
\hline & WW & DS & WW & DS & WW & DS & WW & DS \\
\hline Teshale/B35 & 1.99abcde & $0.61^{\mathrm{cde}}$ & $2.95^{\mathrm{a}}$ & $2.00^{\text {bcde }}$ & $0.78^{\mathrm{abc}}$ & $0.35^{\mathrm{c}}$ & $0.52^{\mathrm{f}}$ & $2.67^{\mathrm{cd}}$ \\
\hline Teshale/E36-1 & $2.41 \mathrm{abc}$ & $1.95^{\mathrm{abcde}}$ & $2.77^{\mathrm{ab}}$ & $1.45^{\mathrm{d}}$ & $0.94^{\mathrm{abc}}$ & $1.50^{\mathrm{abc}}$ & $0.54^{\mathrm{e}}$ & $3.74^{\mathrm{a}}$ \\
\hline Gambella 1107/E36-1 & 2.21abcde & $0.79^{\text {bcde }}$ & $2.39^{\mathrm{abc}}$ & $1.38^{\mathrm{de}}$ & $1.28^{\mathrm{abc}}$ & $0.65^{\mathrm{abc}}$ & $0.53^{\mathrm{e}}$ & $2.78^{c}$ \\
\hline Gambella 1107/B35-code1 & 2.08abcde & $0.68^{\text {cde }}$ & $1.96^{\mathrm{c}}$ & $1.28^{\mathrm{e}}$ & $1.04^{\mathrm{abc}}$ & $0.63^{\mathrm{abc}}$ & $0.54^{\mathrm{e}}$ & $2.67^{\mathrm{cd}}$ \\
\hline Gambella 1107/B35-code5 & $2.57 \mathrm{ab}$ & $1.91^{\mathrm{abcde}}$ & $1.32^{\mathrm{e}}$ & $1.26^{\mathrm{e}}$ & $2.00^{\mathrm{abc}}$ & $1.97^{\mathrm{abc}}$ & $0.55^{\mathrm{e}}$ & $3.49^{\mathrm{abc}}$ \\
\hline Meko/B35-code8 & 1.65abcde & $0.61^{\text {cde }}$ & $1.67^{\text {cde }}$ & $1.03^{\mathrm{fg}}$ & $1.28^{\mathrm{abc}}$ & $1.20^{\mathrm{abc}}$ & $0.51^{\mathrm{f}}$ & $2.69^{\mathrm{cd}}$ \\
\hline Meko/B35-code12 & 2.17abcde & $0.78^{\text {bcde }}$ & $2.12^{\mathrm{b}}$ & $1.41^{\mathrm{de}}$ & $1.08^{\mathrm{abc}}$ & $0.82^{\mathrm{abc}}$ & $0.53^{\mathrm{e}}$ & $3.36^{\mathrm{abc}}$ \\
\hline Teshale & $2.72 \mathrm{a}$ & $0.55^{\mathrm{d}}$ & $1.11^{\mathrm{fg}}$ & $0.64^{\mathrm{fg}}$ & $2.70^{\mathrm{b}}$ & $0.86^{\mathrm{abc}}$ & $0.51^{\mathrm{g}}$ & $2.64^{\mathrm{cd}}$ \\
\hline Gambella 1107 & $2.85 \mathrm{a}$ & $0.74^{\mathrm{c}}$ & $1.44^{\mathrm{de}}$ & $0.88^{\mathrm{fg}}$ & $2.09^{\mathrm{abc}}$ & $1.10^{\mathrm{abc}}$ & $0.52^{\mathrm{e}}$ & $3.07^{\mathrm{b}}$ \\
\hline Meko & 2.31 abcd & $0.66^{\mathrm{cde}}$ & $1.24^{\mathrm{ef}}$ & $0.71^{\mathrm{fg}}$ & $1.94^{\mathrm{abc}}$ & $0.93^{\mathrm{abc}}$ & $0.52^{\mathrm{e}}$ & $3.06^{\mathrm{bc}}$ \\
\hline E36-1 & 2.27abcd & $0.86^{\mathrm{b}}$ & $1.17^{\mathrm{f}}$ & $0.46^{\mathrm{fg}}$ & $2.37^{\mathrm{a}}$ & $2.33^{\mathrm{abc}}$ & $0.51^{\mathrm{g}}$ & $3.73^{\mathrm{ab}}$ \\
\hline B35 & 1.46abcde & $0.44+$ & $0.83^{\mathrm{fg}}$ & $0.37^{\mathrm{g}}$ & $1.89^{\mathrm{abc}}$ & $1.29^{\mathrm{abc}}$ & $0.50^{\mathrm{g}}$ & $2.43^{\mathrm{d}}$ \\
\hline
\end{tabular}

*WW = well-watered, $\mathrm{DS}=$ drought stressed, $\mathrm{AR}=$ assimilation rate $\left(\mathrm{g} \mathrm{cm}^{-2}\right) ; \mathrm{TR}=$ transpiration rate $(\mathrm{mg}$ $\left.\mathrm{m}^{-2} / \mathrm{s}\right) ; \mathrm{WUE}=$ water use efficiency; Prol = proline content $\left(\right.$ ìmol g $\mathrm{g}^{-2}$ fresh weight $)$ 
Gambella 1107/B35-5 and Meko/B35-12, and one of their Stg donor parents (E36-1) whereas the minimum was in Teshale and B35.

Yield and yield related traits. Shoot dry weight (SDW) showed significant differences $(\mathrm{P}<0.05)$ among the genotypes under the two water regimes (data not shown). All of the genotypes had higher SDW under well-watered regime than under water limited condition. Under the stressed condition, Teshale/E36-1 and Gambella 1107/B35-5, had the highest; and B35 had the lowest SDW of all the genotypes. Shoot dry weight among the genotypes ranged from $340.15 \pm 7.10 \mathrm{~g}$ (B35) to $541.12 \pm 14.91 \mathrm{~g}$ (Teshale/E36-1) and from 335.68 $\pm 13.86 \mathrm{~g}$ (B35) to $537.18 \pm 12.39 \mathrm{~g}$ (Teshale/ E36-1) under well-watered and drought stressed conditions, respectively. Under the drought stressed condition, all of the introgression lines except Gambella 1107/E36-1 and Gambella 1107/B35-1 had higher SDW than their recurrent parents (Table 3).

There was a significant difference $(\mathrm{P}<0.05)$ among the genotypes for grain yield, panicle weight and hundred seed weight under the two water regimes (Table 3). A general reduction in panicle weight was observed in all the genotypes, related to drought stress. Under drought stressed condition, Teshale/E36-1, Gambella 1107/B35-5 and E36-1, in that order, showed the highest panicle weight; while, Gambella 1107/B35-1 showed the lowest panicle weight. Under well-watered condition, all of the introgression lines had lower panicle weight than their recurrent parents; but under stressed condition, only four of the seven introgression lines, Teshale/E36-1, Gambella 1107/B35-5, Meko/B35-12 and Meko/B35-8, showed lower panicle weight than their recurrent parents (Table 3).

Due to post-flowering drought stress condition, the 100 seed weight (HSW) of the genotypes ranged from $2.18 \pm 0.12 \mathrm{~g}$ (B35) to $3.65 \pm 0.19 \mathrm{~g}$ (Teshale/E36-1). Under the wellwatered condition, all of the introgression lines had lower HSW than their recurrent parents; but under the stressed condition, all of the introgression lines, except Gambella 1107/B351, Meko/B35-8 and Teshale/B35, had HSW either higher or not significantly different from their recurrent parents (Table 3).

Grain yield of all genotypes exposed to postflowering drought stress was lower than those

TABLE 3. Effect of post-flowering drought stress on shoot dry weight, panicle weight, hundred seed weight, and grain yield for sorghum genotypes in Ethiopia

\begin{tabular}{|c|c|c|c|c|c|c|c|c|}
\hline \multirow[t]{2}{*}{ Genotypes } & \multicolumn{2}{|c|}{$\mathrm{SDW}^{*}$} & \multicolumn{2}{|c|}{ PW } & \multicolumn{2}{|c|}{ HSW } & \multicolumn{2}{|c|}{ GY } \\
\hline & WW & DS & WW & DS & WW & DS & WW & DS \\
\hline Teshale/B35 & $514.99^{\mathrm{abc}}$ & $461.37^{\mathrm{de}}$ & $42.45^{\mathrm{de}}$ & $34.77^{\mathrm{e}}$ & $2.78^{\mathrm{e}}$ & $2.25^{\mathrm{h}}$ & $2.75^{\text {abcdef }}$ & $1.97^{\mathrm{ef}}$ \\
\hline Teshale/E36-1 & $541.12^{\mathrm{a}}$ & $537.18^{\mathrm{a}}$ & $81.46^{\mathrm{abc}}$ & $76.63^{\mathrm{abcd}}$ & $3.80^{\mathrm{abc}}$ & $3.65^{\mathrm{abcde}}$ & $3.85^{\mathrm{abc}}$ & $3.65^{\mathrm{abc}}$ \\
\hline Gambella 1107/E36-1 & $432.10^{\mathrm{e}}$ & $425.06^{\mathrm{e}}$ & $57.55^{\mathrm{d}}$ & $36.71^{\mathrm{de}}$ & $3.02^{\mathrm{b}}$ & $2.66^{\mathrm{f}}$ & $3.39^{\text {abcdef }}$ & $2.87^{\mathrm{abcdef}}$ \\
\hline Gambella 1107/B35-code1 & $423.31^{\mathrm{e}}$ & $405.34^{\mathrm{e}}$ & $46.65^{\mathrm{bc}}$ & $25.83^{\mathrm{f}}$ & $3.00^{c}$ & $2.55^{\mathrm{fgh}}$ & $3.00^{\text {bcdef }}$ & $2.74^{\mathrm{abcdef}}$ \\
\hline Gambella 1107/B35-code5 & $531.52^{\mathrm{ab}}$ & $526.49^{\mathrm{abc}}$ & $76.99^{\mathrm{abcd}}$ & $71.75^{\text {abcde }}$ & $3.71^{\mathrm{abcd}}$ & $3.55^{\text {abcde }}$ & $3.89^{\mathrm{ab}}$ & $3.60^{\mathrm{abcd}}$ \\
\hline Meko/B35-code8 & $452.89^{\mathrm{de}}$ & $425.08^{\mathrm{e}}$ & $56.40^{\text {abcde }}$ & $44.34^{\text {be }}$ & $2.89^{\mathrm{d}}$ & $2.38^{\mathrm{g}}$ & $2.51^{\text {bcdef }}$ & $2.02^{\mathrm{e}}$ \\
\hline Meko/B35-code12 & $473.89^{\mathrm{b}}$ & $467.74^{c}$ & $67.15^{\mathrm{abcde}}$ & $60.58^{\text {abcde }}$ & $3.36^{\mathrm{abcdef}}$ & $3.02^{\text {bcdefgh }}$ & $3.28^{\mathrm{abcdef}}$ & $3.29^{\mathrm{abcdef}}$ \\
\hline Teshale & $539.30^{\mathrm{a}}$ & $456.27^{\text {de }}$ & $85.78^{\mathrm{ab}}$ & $52.46^{\mathrm{b}}$ & $3.90^{\mathrm{ab}}$ & $2.58^{\mathrm{fgh}}$ & $4.04^{\mathrm{ab}}$ & $2.03^{\mathrm{def}}$ \\
\hline Gambella 1107 & $527.13^{\mathrm{abc}}$ & $463.57^{\mathrm{d}}$ & $89.42^{\mathrm{a}}$ & $54.84^{\text {abcde }}$ & $3.91^{\mathrm{a}}$ & $2.60^{\mathrm{fgh}}$ & $4.23^{\mathrm{a}}$ & $2.52^{\mathrm{b}}$ \\
\hline Meko & $449.89^{\mathrm{e}}$ & $413.50^{\mathrm{e}}$ & $68.93^{\text {abcde }}$ & $43.84^{\mathrm{c}}$ & $3.58^{\mathrm{abcde}}$ & $2.56^{\text {fgh }}$ & $3.74^{\mathrm{abc}}$ & $2.28^{c}$ \\
\hline E36-1 & $431.83^{e}$ & $428.60^{\mathrm{e}}$ & $70.47^{\text {abcde }}$ & $63.25^{\text {abcde }}$ & $3.41^{\text {abcdef }}$ & $3.17^{\text {abcdefg }}$ & $3.48^{\mathrm{abcde}}$ & $3.16^{\text {abcdef }}$ \\
\hline B35 & $340.15^{\mathrm{f}}$ & $335.68^{\mathrm{f}}$ & $40.09^{\mathrm{ce}}$ & $34.63^{\mathrm{e}}$ & $2.31^{\mathrm{gh}}$ & $2.18^{\mathrm{h}}$ & $2.03^{\mathrm{d}}$ & $1.89^{\mathrm{f}}$ \\
\hline
\end{tabular}

*WW = well-watered; DS = drought stressed; SDW = shoot dry weight $(\mathrm{gm}) ; \mathrm{PW}=$ panicle weight $(\mathrm{gm}) ; \mathrm{HSW}$ $=$ hundred seed weight $(\mathrm{gm}) ; \mathrm{GY}=$ grain yield $\left(\mathrm{t} \mathrm{ha}^{-1}\right)$ 
under well-watered condition (Table 3). Grain yield ranged from $2.03 \mathrm{t} \mathrm{ha}^{-1}$ (B35) to $4.23 \mathrm{t}$ $\mathrm{ha}^{-1}$ (Gambella 1107) under well-watered condition and from $1.89 \mathrm{t} \mathrm{ha}^{-1}$ (B35) to $3.65 \mathrm{t}$ ha $^{-1}$ (Teshale/E36-1) under drought stress growing condition. Under well-watered condition, all the introgression lines had lower grain yield than their recurrent parents, but under water limited condition, all the introgression lines, except Meko/B35-8 and Teshale/B35, had higher grain yield than their recurrent parents.

Correlations among the measured parameters. The Pearson's coefficient of correlation among the various parameters measured under drought stressed condition showed that $\mathrm{CO}_{2}$ assimilation rate had a significant positive correlation with WUE $(\mathrm{r}=0.63)$, proline content $(\mathrm{r}=0.56)$, HSW $(\mathrm{r}=$ $0.55), \mathrm{SDW}(\mathrm{r}=0.62)$ and grain yield $(\mathrm{r}=0.52)$. Moreover, proline content had a very strong positive correlation with HSW ( $\mathrm{r}=0.74)$, SDW $(\mathrm{r}=0.59)$, panicle weight $(\mathrm{r}=0.72)$, and grain yield $(r=0.70)$. The correlation of SDW $(r=0.64)$, panicle weight $(r=0.70)$ and with grain yield $(r=0.68)$ was very strong and positive. Maximum proline content was observed in better yielding lines, Teshale/E361, Gambella 1107/B35-5 and Meko/B35-12, and one of their Stg donor parents (E36-1) whereas the minimum was in Teshale and B35.

\section{DISCUSSION}

Stay green trait. Leaves of the recurrent parents senesced more than both the donor parents and their introgression lines under induced drought condition (Table 1). Similarly, high leaf senescence under post-flowering drought condition was reported by Farooq $e t$ al. (2009) and Bezabih (2012). Water deficit reduces individual leaf size and leaf longevity by increasing leaf senescence and by decreasing the soil's water potential (Anjum et al., 2011a). However, the response varies depending on the genotype's ability to maintain green leaf area.
A relatively lower leaf senescence rating was observed in Stg donor lines, B35 and E361, and their QTL introgression lines Meko/ B35-12, Gambella 1107/B35-5 and Teshale/ E36-1, under drought stressed condition (Table 1), perhaps due to the Stg trait. The higher rate of maintenance of green leaf area in B35 was in agreement with Kassahun (2006) who compared different genotypes of sorghum for drought tolerance in relation to stay green trait. The Stg trait results in greater functional photosynthetic leaf area during grain filling and after physiological maturity (Sanchez et al., 2002). The higher leaf senescence rating in the recurrent parents, Gambella 1107, Meko and Teshale, under stressed condition could be due to absence of Stg trait. This may also suggest that the induced water deficit sufficiently severed to differentiate the senescent genotypes from non-senescent $(\mathrm{Stg})$ ones. Previous reports also suggested that drought stress during the post-flowering period accelerates senescence of non-Stg sorghum genotypes (Wingler et al., 2006; Borrell et al., 2014).

Physiological parameters. In the present study, it has been found that induced postflowering water deficit decreases chlorophyll content of all the test genotypes (Table 1). This was in agreement with previous studies (Mostafa et al., 2011; Sharada and Naik, 2011). In line with the result of the present study, Khayatnezhad and Gholamin (2012) reported that chlorophyll content of both resistant and sensitive cultivars reduced under drought stress.

The reduction in chlorophyll content under drought stressed condition could be due to thylakoid membrane damage, caused by increased production of reactive oxygen species (Kapanigowda et al., 2013). It has been reported that post-flowering drought resistant genotypes have higher chlorophyll content than susceptible genotypes (Arjenaki et al., 2012). Such phenomenon of retaining higher chlorophyll content under water deficit condition serves as a water deficit stress 
tolerance mechanism in sorghum genotypes with Stg property (Thomas and Howarth, 2000). Similarly, in the present study, B35, Teshale/B35, E36-1 and Teshale/E36-1 maintained the highest chlorophyll content under water deficit condition and can be tentatively considered as tolerant to post flowering drought stress. In addition, high chlorophyll content indicates a low degree of photoinhibition of photosynthetic apparatus and is, thus desirable (Almeselmani, 2011). On the other hand, a decrease in chlorophyll content with drought stress implies a lowered capacity for light harvesting (Mafakheri et al., 2010) due to the reduced efficiency of light capturing to drive photosynthesis (Anjum et al., 2011b).

Relative water content (RWC) is considered as a measure of plant water status, reflecting the metabolic activity in tissues and serves as the most meaningful measurements for drought tolerance. In the present study, drought stress brought about a dramatic decline in RWC in all the genotypes (Table 1). This was in agreement with the previous reports (Keyvan, 2010; Unyayar et al., 2004; Xu et al., 2000) that induced drought stress in sorghum significantly affected RWC. This reduction might be triggered by water deficit in the soil and/or as a consequence of water loss via the stomata (Keyvan, 2010). Under the drought stressed condition, the Stg donor parents (B35 and E36-1) maintained the greatest mean RWC of all genotypes (Table 1) perhaps because Stg character helped them to keep the stalk transportation system functioning under this conditions (Xu and Zhou, 2008). The Stg trait resulted in decreased water use early in the season and allowed water to be conserved to sustain a longer period of grain filling (Kapanigowda et al., 2013). Teshale/ E36-1, Meko/B35-12, and Gambella 1107/B35-5 had superior RWC to the other introgression lines, and recurrent parents under the drought stressed condition. Genotypes that keep their stomata open under the drought stress conditions and maintain adequate RWC can be in general considered as suitable for dry regions (Krouma, 2010). In this regard, the above mentioned genotypes could be suitable for dry regions of Ethiopia.

In general, introgression lines and their parents showed a decline in assimilation rate under post-flowering drought stress (Table 2). This was in agreement with previous reports (Griffiths and Parry, 2002; Krouma, 2010). Assimilation rate is particularly affected by water deficiency, which causes functional and structural rearrangements of photosynthesizing apparatus (Griffiths and Parry, 2002). On the other hand, the observed decline in assimilation rate might be due to a decrease in RWC, which leads to turgor loss of guard cells, causing passive stomatal closure. This leads to a decrease in $\mathrm{CO}_{2}$ uptake and lets the plants consume a lot of energy to absorb water, which in turn causes a reduction in photosynthesis (Valadabadi et al., 2009).

The decline in the rate of $\mathrm{CO}_{2}$ uptake was observed in the studied genotypes, except Teshale/E36-1 and Gambella 1107/B35-5 (Table 2). However, Teshale/E36-1, B35 and Gambella 1107/B35-5 showed less sensitivity to drought stress condition, implying their better tolerance to drought stress than the rest of the tested genotypes. The comparable photosynthetic performance of these lines with the known post-flowering drought resistant donor parents (B35 and E36-1), could be evidence of better assimilation rate under severe water deficit conditions. In contrast, the higher sensitivity of Teshale to declining soil moisture as evident from the lowest $\mathrm{CO}_{2}$ uptake shows its sensitivity to drought stress. This observation suggests that the higher chlorophyll content of Teshale/B35 and Meko/ B35-8 was not associated with high assimilation rate. Therefore, maintenance of green leaf area in Teshale/B35 and Meko/B358 was probably cosmetic or non-functional type (Thomas and Howarth, 2000).

Even though, in general terms, sorghum genotypes possessing the $S t g$ trait retain green stems and leaves continue to photosynthesize even under terminal drought stress than those 
that do not have this trait (Harris et al., 2007), this happens only if Stg is associated with assimilation rate, which is functional Stg. Thus, assimilation rate is a useful criterion in differentiating drought tolerant genotypes from sensitive ones; and those with cosmetic and non-cosmetic/ functional Stg types.

In conformity with previous studies (Mafakheri et al., 2010; Kapanigowda et al., 2013), genotypes revealed a general trend of reduction in transpiration rate under the drought stressed condition (Table 2). The transpiration rates of genotypes under the wellwatered condition were higher than those under stressed condition. Stomatal closure is probably responsible for the decline in transpiration rate in tolerant genotypes, under the drought stressed condition, as it is the most efficient way of reducing transpirational water loss (Yordanov et al., 2001). In contrast, Teshale/B35 and Teshale/E36-1 had higher transpiration efficiency under the drought stressed condition, which might be due to the presence of the Stg trait. Similarly, Borrell et al. (2003) reported that some genotypes with Stg characteristics possessed enhanced transpiration efficiency, which enable the plant to set a higher yield potential during anthesis, which ultimately leads to higher grain yield.

E36-1, Gambella 1107/B35-5 and B35 had higher WUE, which is an indication of improved drought tolerance by optimising $\mathrm{CO}_{2}$ uptake per unit of water lost through transpiration. This was possibly done through maintaining better RWC and opening of stomata partially, which allowed a relatively higher assimilation and a reduced transpiration (Cornic, 2000). Van Oosterom et al. (2006) suggested Stg to be the consequence of water saving from having higher WUE. Furthermore, the reduced WUE of Teshale/B35 and Gambella 1107/B35-1 was perhaps due to extensive stress-induced leaf senescence. Therefore, WUE indicates the tissue water relation of sorghum lines and their parents and suggests the difference in adaptation strategies among the genotypes to drought stress.
Proline content. Leaf proline content of the tested introgression lines and their parents under water stressed condition showed significant variation (Table 2). The minimum proline content in the Stg donor line, B35, though difficult to explain, may indicate that the induced drought was not severe for it to accumulate high proline. It is known that proline is among the several osmolytes, whose accumulation increases when the plants experience some kind of stress such as drought and salt as a defensive mechanism (Reddy et al., 2015). Accumulation of proline under the stress condition was reported to have correlated with stress tolerance, and its concentration has been shown to be generally higher in stress tolerant than in stress sensitive plants (Pirdashti et al., 2009; Sharada and Naik, 2011).

Yield and yield related traits. A significant reduction in SDW under drought stress condition was observed in all of the genotypes studied (Table 3), which was in agreement with Valadabadi et al. (2009) and Anjum et al. (2011a). The observed reduction in SDW was perhaps due to the reduction in photosynthesis as a result of leaf area reduction, decrease in chlorophyll synthesis and the rise in the energy consumed by the plant in order to take in water (Valadabadi et al., 2009). The effect of drought stress is mainly observed in the form of decreasing in SDW (Hamayun, 2010). The maximum SDW was recorded by Teshale/ E36-1, Gambella 1107/B35-5 and Meko/B3512; while the minimum SDW was recorded by B35 under the stressed condition (Table 3). Sorghum genotypes with Stg trait had higher shoot dry matter accumulation at maturity, indicating that grain filling occurs because of current photosynthesis rather than remobilisation from stem reserves, which was in agreement with the results of Renuka and Chimmad (2006). This is expected because SDW production and accumulation in plants is mainly the result of photosynthesis, which requires water (Okiyo et al., 2008). The 
variation in SDW under drought stress conditions would help screen tolerant genotypes from sensitive as tolerant genotypes have less reduction in shoot dry matter than susceptible ones under water deficit stress conditions (Pace et al., 1999).

Post-flowering drought stress caused reduction in grain yield and panicle weight in all of the genotypes (Table 3). The reduction in grain yield was the highest for Teshale followed by Gambella 1107 and Meko, all of which were susceptible recurrent parents. This was in agreement with the reports of Asgharipour and Heidari (2011), who found significant reduction in grain yield. Moreover, Tuinstra et al. (1997) reported that the effect of post-flowering drought stress on sorghum grain yield was significant compared to wellwatered condition. The reduction of grain yield of sorghum genotypes could be a result of fewer seeds per unit area and smaller size of the panicle (Ibrahim et al., 2013). It was also clear that Teshale/E36-1 and Gambella 1107/ B35-5 had superior grain yield and panicle weight under drought stress to the Stg donor parent (E36-1) (Table 3). The Stg donor parent B35 had the lowest grain yield overall, which was in line with the reports of Adugna and Tirfessa (2014) and Kassahun et al. (2010), who reported that B35 was generally low yielder due to its small panicle size and low grain number per panicle. On the other hand, the observed high grain yield in Teshale/E361 and Gambella 1107/B35-5 was consistent with relatively higher assimilation rate, high panicle weight, and HSW under stressed condition (Table 3).

Low transpiration rate in E36-1 that resulted in higher WUE (Table 2) could have favoured high assimilation, ultimately better grain yield under drought stress. The lowest grain yield of B35, Teshale/B35 and Meko/B358 was also reflected in parallel decline in assimilation rate. This might be due to the fact that grain development is related to assimilation rate during anthesis and is sensitive to water stress (Tuinstra et al., 1997), which might have caused reduced HSW. Similar to this study, Kassahun (2006) found significantly lower biomass, grain size and grain yield in the majority of B35 sorghum backcross derivatives to their elite recurrent parents, which were attributed to the effect of undesirable linkage drag.

A general reduction in HSW was observed among lines and their parents under water stressed condition (Table 3), which was in agreement with the results of Rosenow and Clark (1995). This might be as a result of the decline in photosynthetic capacity and lack of enough assimilates to fill the developing grains (Tuinstra et al., 1997). Under the stressed condition, some of the Stg introgression lines had higher grain weight than their senescent recurrent parents (Table 3), which suggests the contribution of Stg QTLs for continued photosynthesis and accumulation of assimilates under post-flowering drought condition.

Relationship among parameters. Proline content had significant positive correlation with assimilation rate and grain yield under drought stress (Table 1). The positive and significant correlation of proline content with other measurements proves its importance as a selection criterion for Stg QTL introgression lines under post-flowering drought stress. The correlation between AR and GY under stress was in conformation with previous reports in rice (Pirdashti et al., 2009; Kumar et al., 2014) and in bread wheat (Keyvan, 2010).

Hundred seed weight (HSW) showed significant positive correlation with SDW, panicle weight (PW) and grain yield (Supplementary Table). This confirms that HSW, SDW and PW are the components of grain yield. Moreover, the above correlations indicate the potential and relevance of physiological measurements in determining Stg property and drought tolerance in sorghum genotypes. Thus, proline content, $\mathrm{CO}_{2}$ assimilation and HSW could be useful in 
determining yield of sorghum under postflowering drought stress, and are fairly effective parameters for evaluation of drought tolerance.

\section{CONCLUSION}

The present study indicates the existence of variability among Stg QTL introgression sorghum lines developed through molecular marker assisted breeding in 2006 - 2008 in Ethiopia, in terms of their reaction to measured parameters under post-flowering drought stress. The following Stg QTL introgression sorghum lines were selected based on their drought stress tolerance and having relatively higher yield potential under drought: Teshale/ E36-1, Gambella 1107/B35-5 and Meko/B3512. Two of the lines: Teshale/E36-1 and Meko/ B35-12 were also found to show better performance in our previous study. The results also showed that Stg QTL introgression sorghum lines had a remarkable variation for contrasting characters in response to terminal drought conditions. Based on the present study, proline content, $\mathrm{HSW}$ and $\mathrm{CO}_{2}$ assimilation are recommended as screening tools for Stg property, due to their strong correlation with other measurements. The response of the genotypes should be further assessed in the actual multi-location sorghum growing areas that are affected by terminal moisture stress, in order to investigate the effect of QTL x Environment interaction.

\section{ACKNOWLEDGEMENT}

We acknowledge the Sorghum Research Programme of the Ethiopian Institute of Agricultural Research for providing with the study materials. ICRISAT Nairobi is also acknowledged for the MAS. We thank Addis Ababa University, Department of Plant Biology and Biodiversity Management for providing with laboratory facilities.

\section{REFERENCES}

Adugna, A. 2007. The role of introduced sorghum and millets in Ethiopian agriculture. SAT e-Journal 3:1-9.

Adugna, A. and Tirfessa, A. 2014. Response of stay green quantitative trait locus (QTL) introgression sorghum lines to post anthesis drought stress. African Journal of Biotechnology 13(49):4492-4500.

Ali, M.A., Abbas, A., Awan, S.I., Jabran, K. and Gardezi, S.D.A. 2011. Correlated response of various morpho-physiological characters with grain yield in sorghum landraces at different growth phases. Journal of Animal and Plant Science 21(4):671-679.

Almeselmani, M. 2011. Effect of drought on different physiological characters and yield component in different varieties of Syrian durum wheat. Journal of Agricultural Science 3(3):127-133.

Anjum, S.A., Xie, X., Wang, L., Saleem, M.F., Man, C. and Lei, W. 2011a. Morphological, physiological and biochemical responses of plants to drought stress. African Journal of Agricultural Research 6(9):2026-2032. Anjum, S.A., Farooq, M., Wang, L.C., Xue, L.L., Wang, S.G., Wang, L., Zhang, S., Chen, M. 2011b. Gas exchange and chlorophyll synthesis of maize cultivars are enhanced by exogenously-applied glycinebetaine under drought conditions. Plant Soil and Environment 57(7):326331.

Arjenaki, F.G., Jabbari, R. and Morshedi, A. 2012. Evaluation of drought stress on relative water content, chlorophyll content and mineral elements of wheat (Triticum aestivum L.) varieties. International Journal of Agriculture and Crop Science 4(11):726729.

Asgharipour, M.R. and Heidari, M. 2011. Effect of potassium supply on drought resistance in sorghum: plant growth and 
macronutrient content. Pakistan Journal of Agricultural Science 48(3):197-204.

Barrs, H.D. 1968. Determination of water deficits in plant tissue. In: Kozlowski, T.T. (Ed.) Water deficits and plant growth. Academic Press. New York, USA 1: 235368.

Barrs, H.D. and Weatherley, P.E. 1962. A reexamination of the relative turgidity techniques for estimating water deficits in leaves. Australian Journal of Biological Sciences 15:413-428.

Bates, L., Waldren, R. and Teare, I. 1973. Rapid determination of free proline in water stress studies. Plant and Soil 39:205-208.

Bekele, M. 2001. Forestry Outlook Studies in Africa (FOSA): Ethiopia. FAO corporate document repository. http://www.fao.org/ 3/a-ab582e.pdf.

Bezabih, A. 2012. Evaluation of stay-green quantitative trait loci (QTLS) introgression Sorghum (Sorghum bicolor (L.) Moench) lines for post-flowering drought resistance at kobo, north eastern Ethiopia. MSc. Thesis, Haramaya University, Ethiopia.

Borrell, A., Van Oosterom, E., Hammer, G., Jordan, D. and Douglas, A. 2003. The physiology of "stay-green" in sorghum. In: Proceedings of the $11^{\text {th }}$ Australian Agronomy Conference, 2-6 February 2003, Geelong, Victoria, Australia.

Borrell, A.K., Mullet, J., George-jaeggli, B., Van oosterom E.J., Hammer G.L., Klein, P.E. and Jordan, D.R. 2014. Drought adaptation of stay-green sorghum is associated with canopy development, leaf anatomy, root growth, and water uptake. Journal of Experimental Botany 65 (21):6137-6139.

Borrell, A.K., Hammer, G.L. and Douglas, A.C.L. 2000. Does maintaining green leaf area in sorghum improve yield under drought? Leaf growth and senescence. Crop Science 40:1026-137.

Chamberlin, J. and Schmidt, E. 2011. Ethiopian agriculture: A dynamic geographic perspective. International Food Policy
Research Institute. Ethiopia Strategy Support Program II (ESSP II) Working Paper No. 017.

Cornic, G. 2000. Drought stress inhibits photosynthesis by decreasing stomatal aperture: Not by affecting ATP synthesis. Trends in Plant Science 5:187-188.

Dahlberg, J., Berenji, J., Sikora, V. and Latkovic, D. 2011. Assessing sorghum (Sorghum bicolor L. Moench) germplasm for new traits: food, fuels and unique use. Maydica 1: 85-92.

Farooq, M., Wahid, A., Kobayashi, N., Fujita, D. and Basra, S.M.A. 2009. Plant drought stress: Effects, mechanisms and management. Agronomy for Sustainable Development 29:185-212.

Griffiths, H. and Parry, M.A.J. 2002. Plant responses to water stress. Annals of Botany 89(7):801-802.

Hamayun, M., Khan, S.A., Shinwari, Z.K., Khan, A.L., Nadeem Ahmad, N. and InJung Lee, I.J. 2010. Effect of polyethylene glycol induced drought stress on physiohormonal attributes of soybean. Pakistan Journal of Botany 42(2):977-986.

Harris, K., Subudhi, P.K., Borrell, A., Jordan, D., Rosenow, D., Nguyen, H., Klein, P., Klein, R. and Mullet, J. 2007. Sorghum stay-green QTL individually reduce postflowering drought-induced leaf senescence. Journal of Experimental Botany 58(2):327-338.

He, P., Osaki, M., Takebe, M., Shinano, T. and Wasaki, J. 2005. Endogenous hormones and expression of senescencerelated genes in different senescent types of maize. Journal of Experimental Botany 56 (414):1117-1128.

Ibrahim, A.H., El-Shahaby, O.A., Abo-Hamed, S.A. and Younis, M.E. 2013. Parental drought and defoliation effect on yield, grains biochemical aspects and drought performance of sorghum progeny. Journal of Stress Physiology and Biochemistry 9(1):258-272. 
ICRISAT (International Crops Research Institute for the Semi-Arid Tropics). 2013. Virtual academy for semi-arid tropics: sorghum. Andhra Pradesh, India.

Kapanigowda, M.H., Perumal, R., Djanaguiraman, M., Aiken, R.M., Tesso, T., Prasad, P.V. and Little, C.R. 2013. Genotypic variation in sorghum [Sorghum bicolor (L.) Moench] exotic germplasm collections for drought and disease tolerance. SpringerPlus 1:13.

Kassahun, B. 2006. Mapping of simple sequence repeat (SSRs) and marker assisted introgression of QTL for staygreen in sorghum. $\mathrm{PhD}$ Thesis. University of Agricultural Sciences, Dharwad, India.

Kassahun, B., Bidinger, F.R., Hash, C.T. and Kuruvinashetti, M.S. 2010. Stay-green expression in early generation Sorghum [Sorghum bicolor (L.) Moench] QTL introgression lines. Euphytica 172:351362.

Keyvan, S. 2010. The effects of drought stress on yield, relative water content, proline, soluble carbohydrates and chlorophyll of bread wheat cultivars. Journal of Animal and Plant Science 8(3):1051-1060.

Khayatnezhad, M. and Gholamin, R. 2012. The effect of drought stress on leaf chlorophyll content and stress resistance in maize cultivars (Zea mays). African Journal of Microbiology Research 6(12):2844-2848.

Krouma, A. 2010. Plant water relations and photosynthetic activity in three Tunisian Chickpea (Cicer arietinum L.) genotypes subjected to drought. Turkish Journal of Agriculture \& Forestry 34:257-264.

Kumar, S., Dwivedi, S.K., Singh, S.S., Jha, S.K., Lekshmy, S., Elanchezhian, R., Singh, O.N. and Bhatt, B.P. 2014. Identification of drought tolerant rice genotypes by analyzing drought tolerant rice genotypes by analyzing drought tolerance indices and morpho-physiological traits. SABRAO Journal of Breeding \& Genetics 46(2):217-230.

Mafakheri, A., Siosemardeh, A., Bahramnejad, B., Struik, P.C. and Sohrabi, Y. 2010. Effect of drought stress on yield, proline and chlorophyll contents in three chickpea cultivars. Australian Journal of Crop Science 4(8):580-585.

Mostafa, M., Shahbazi, M., Khazaei, A., and Daneshian, J., Naddafi, S. and Pourirandoust, H. 2011. Effect of post flowering water stress on yield and physiological characters of grain sorghum genotypes. Iranian Journal of Plant Physiology 2(1):343-346.

Okiyo T., Gudu, S., Kiplagat, O. and Owuoche, J. 2008. Effect of post anthesis moisture stress on performance of stay green sorghum hybrid in eastern province of kenya. African Crop Science Journal 18:130-135.

Ozturk, A.F. and Aydin, L. 2004. Effect of water stress at various growth stages on some quality characteristics of winter wheat. Journal of Agronomy and Crop Science 190:93-99.

Pace, P.F., Cralle, H.T., El-Halawany, S.H.M., Cothren, T. and Senseman, S.A. 1999. Drought induced changes in shoot and root growth of young cotton plants. Journal of Cotton Science 3:183-187.

Pirdashti, H., Sarvestani, Z.T. and Bahmanyar, M.A. 2009. Comparison of physiological responses among four contrasting rice cultivars under drought stress condition. World Academy of Science, Engineering and Technology 49:52-53.

Reddy, M.S. and Georgis, K. 1993. Dryland farming research in Ethiopia: Review of the past and thrust in the nineties. Institute of Agricultural Research, Addis Ababa, Ethiopia.

Reddy, B.V.S, Ramesh, S., Reddy, P.S. and Kumar, A.A. 2009. Genetic enhancement for drought tolerance in sorghum. In: Janick, J. (Ed.), Plant breeding reviews. John Willey \& Sons, Inc. USA pp. 189222. Doi: 10.1002/9780470593783.ch3,

Reddy, P., Jogeswar, G., Rasineni, G.K., Maheswari, M., Reddy, A.R., Varshney, R.K. and Kishor, P.B.K. 2015. Proline overaccumulation alleviates salt stress and 
protects photosynthetic and antioxidant enzyme activities in transgenic sorghum [Sorghum bicolor (L.) Moench]. Plant Physiology and Biochemistry 94:104-113.

Renuka, K. and Chimmad, V.P. 2006. Effect of irrigation at different post anthesis stages on stay green trait in rabi sorghum genotypes-morpho-phenological characters, yield and yield components. Karnataka Journal of Agricultural Science 19(3):529-534.

Rosenow, D.T. 1993. Breeding for drought resistance under field conditions. In: Proceedings $18^{\text {th }}$ Biennal Grain Sorghum Research and Utilization Conference, February 28, March Lubbock, Texas.

Rosenow, D.T. and Clark, L.E. 1995. Drought and lodging resistance for a quality sorghum crop. In: Proceedings of the $50^{\text {th }}$ Annual Corn and Sorghum Industry Research Conference, Chicago, pp. 82-97.

Rosenow, D.T., Quisenberry, J.E. and Wendt, C.W. 1983. Drought tolerant sorghum and cotton germplasm. Agricultural Water Management 7:207-222.

Sanchez, A.C., Subudhi1, P.K., Rosenow, D.T. and Nguyen, H.T. 2002. Mapping QTLs associated with drought resistance in sorghum [Sorghum bicolor (L.) Moench]. Plant Molecular Biology 48:713-726.

Sharada, P. and Naik, G.R. 2011. Physiological and biochemical responses of groundnut genotypes to drought stress. World Journal of Science and Technology 1(11):60-66.

Sintayehu, S., Adugna, A., Fetene, M., Tirfessa, A. and Ayalew, K. 2018. Study of growth and physiological characters in stay-green QTL introgression Sorghum bicolor (L.) lines under post-flowering drought stress. Cereal Research Communications 46(1):54-66. DOI: 10.1556/0806.45.2017.061.

Thomas, H. and Howarth, C.J. 2000. Five ways to stay green. Journal of Experimental Botany 51:329-337.

Tuinstra, M.R., Grote, E.G., Goldsbrough, P.B. and Ejeta, G. 1997. Genetic analysis of post- flowering drought tolerance and components of grain development in Sorghum bicolor (L.) Moench. Molecular Breeding 3:439-448.

Unyayar, S., Keles, Y. and Unal, E. 2004. Proline and ABA levels in two sunflower genotypes subjected to water stress. Bulgarian Journal of Plant Physiology 30(3-4):34-47.

Vadala, A.A. 2009. Understanding famine in Ethiopia: Poverty, politics and human rights. In: Ege, S., Aspen, H., Teferra B. and Bekele S (Eds.). Proceedings of the 16th International Conference of Ethiopian Studies. Trondheim, Norway. pp. 10711088.

Van-Oosterom E., Hammer, G.L., Borrell, A.K. and Broad, I.J. 2006. What determines expression of stay-green under postanthesis drought stress. In: $5^{\text {th }}$ Australian Sorghum Conference, Gold Coast, Qld, Australia. pp 1-10.

Wingler, A., Purdy, S., MacLean, J.A. and Pourtau, N. 2006. The role of sugars in integrating environmental signals during the regulation of leaf senescence. Journal of Experimental Botany 57(2):391-399.

$\mathrm{Xu}, \mathrm{W} .$, Rosenow, D.T. and Nguyen, H.T. 2000. Stay green trait in grain sorghum: Relationship between visual rating and leaf chlorophyll concentration. Plant Breeding 119:365-367.

Xu, Z. and Zhou, G. 2008. Response of leaf stomatal density to water status and its relationship with photosynthesis in a grass. Journal of Experimental Botany 59(12):3317-3325.

Yordanov, I., Tsonev, T., Velikova, V., Georgieva, K., Ivanov, P., Tsenov, N. and Petrova, T. 2001. Change in $\mathrm{CO} 2$ assimilation, transpiration and stomatal resistance of different wheat cultivars experiencing drought under field conditions. Bulgarian Journal of Plant Physiology 27(3-4):20-23. 